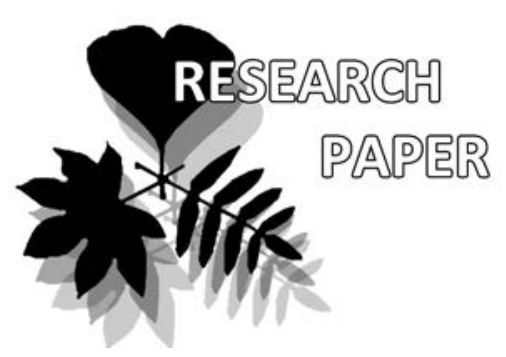

\title{
Development of soybean somatic embryos under different light spectra
}

\author{
Anastasiya V. Micheeva ${ }^{1}$, Olga V. Nakonechnava ${ }^{1 *}$, \\ Evgeniy P. Subbotin ${ }^{2}$, Olga V. Grishchenko ${ }^{1}$, Irina V. Gafitskaya ${ }^{1}$ \\ \& Yuri N. Kulchin ${ }^{2}$
}

Anastasiya V. Micheeva ${ }^{1}$

e-mail: dostik333@gmail.com

Olga V. Nakonechnaya ${ }^{1 *}$

e-mail: markelova@biosoil.ru

Evgeniy P. Subbotin ${ }^{2}$

e-mail: s.e.p@list.ru

Olga V. Grishchenko ${ }^{1}$

e-mail: grishchenkoov@gmail.com

Irina V. Gafitskaya ${ }^{1}$

e-mail: gafitskaya@biosoil.ru

Yuri N. Kulchin ${ }^{2}$

e-mail: kulchin@iacp.dvo.ru

${ }^{1}$ Federal Scientific Center of the East Asia Terrestrial Biodiversity FEB RAS,

Vladivostok, Russia

${ }^{2}$ Institute of Automation and Control Processes FEB RAS, Vladivostok, Russia

\section{* corresponding author}

Manuscript received: 24.12 .2020

Review completed: 15.03.2021

Accepted for publication: 20.04.2021

Published online: 23.04.2021

\begin{abstract}
A B S T R A C T
Soybean (Glycine max (L.) Merr. cv. 'Primorskaya 28') plantlet development from somatic embryos (embryoids) under different spectra was studied. Light irradiation with intensity of $48 \mu \mathrm{mol} /\left(\mathrm{m}^{2} \cdot \mathrm{s}\right)$ was generated by LEDs (light emitting diodes) with various spectra: cold white (CW), white (W), warm white (WW), full spectrum $(\mathrm{FS}, 450 \mathrm{~nm}$ and $660 \mathrm{~nm})$, red $(\mathrm{R}, 630 \mathrm{~nm})$, blue $(\mathrm{B}, 440 \mathrm{~nm})$, and sun box (SB, close to the sun spectrum at wavelength range 440-660 nm). Fluorescent lamps were used as a control illumination $(K)$. Our results showed that experimental LED lights with different spectra possessed the potential to positively affect the development of soybean plantlets from embryoid phase to a full-fledged plantlet, ready to be transferred into soil. The best effect was observed for the FS, which provided development of the highest plantlets. SB light was promising after one month of cultivation, but provided no significant differences in plantlets growth at the end of the experiment. A tendency to the lower growth was observed for plantlets under $\mathrm{CW}, \mathrm{W}, \mathrm{WW}$, and $\mathrm{K}$. Red light did not provide notable shoot elongation, as was supposed to. Investigations will be continued to clarify and refine the obtained data on the effect of light spectra on soybean plantlet development from embryoids.
\end{abstract}

Keywords: Glycine max, embryoid, in vitro, plant growth, artificial light, light emitting diodes, different spectra

\section{P E 3 Ю M E}

Михеева А.В., Наконечная О.В., Субботин Е.П., Грищенко О.В., Гафицкая И.В., Кумьчин Ю.Н. Развитие соматических эмбриоидов сои под разцичными спектрами света. Изучено развитие микрорастений сои (Glycine max (L.) Merr. сорт «Приморская 28») из соматических зародышей (эмбриоиАов) при использовании разАичных спектров освещения. Аля эксперимента использовали полихромные светодиодные (CA) источники с интенсивностью освещения 48 мкмоль $/\left(\mathrm{M}^{2} \cdot \mathrm{c}\right)$ и с разАичными спектрами: холодный белый (CW), белый (W), теплый белый (WW), полный спектр (FS, 450 нм и 660 нм), красный (R, 630 нм), синий (B, 440 нм) и солнечный бокс (SB, спектр близок к солнечному спектру в Аиапазоне Алин волн 440-660 нм). В качестве контрольного освещения (К) использовали мюминесцентные мампы. Результаты исследования показали, что экспериментальные светодиодные мампы с разАичными спектрами облаАают потенциалом положительно вАиять на развитие эмбриоиАов сои АО полноценного микрорастения, готового к переносу в почву. Наилучший эффект наблюдался у микрорастений, выращенных под источником света $\mathrm{FS}$, обеспечившим развитие самых высоких растений. Свет светильника SB был перспективным в течение первого месяца культивирования, но не обеспечил значительных отличий в росте проростков в конце эксперимента. Тенденция к низкому росту наблюдалась у проростков в условиях вариантов белого света (CW, W, WW и K). Красный свет не обеспечивац заметного удАинения побегов, как предполагалось. Исследования будут продолжены Аля уточнения и Аополнения полученных Аанных о вАиянии разных спектров освещения на развитие проростков сои из соматических зародышей.

КАючевые слова: Glycine max, эмбориоиА, in vitro, рост растений, светодиоды, разные спектры
In the world agricultural production soybean (Glycine $\max (\mathrm{L}$.$) Merr.) is one of the main legumes. With the help$ of this culture a problem of producing vegetable protein of full value has been solved.

It is a self-pollinated species with low genetic variation. The latter can be expanded by induction of somatic embryogenesis, i.e. the formation of embryoid structures (embryoids or somatic embryos) in the cell culture without any additional mutagens. Somatic embryogenesis is a process of a plant development from a single haploid or diploid somatic cell through characteristic embryological stages without gamete fusion (Williams \& Maheswaran 1986). Regenerated plants are considered to be clones, differing at the same time from the parent plant by one or several characters (Larkin \& Scowcroft 1981).

The literature data on the G. max embryoids development under different illumination spectra are fragmentary. A comparison of soybean plant growth under light-emitting 
diodes (LEDs) illumination with different emission spectra (white and blue-red spectra) was conducted previously (Ushakova et al. 2016). According to the results, the effect of different light spectra on plant growth was cultivar-specific, and red-blue light either did not influence plant development, or resulted in total plant biomass and seed number decrease, compared to the plants grown under white LEDs (Ushakova et al. 2016).

Bonacin et al. (2000) studied the embryogenic capability of five soybean cultivars (Renascença, IAS-5, IAC-17, BR16, and FT-Cometa) at different light intensity, auxin concentrations, and medium $\mathrm{pH}$. The results showed the influence of genotype on somatic embryogenic capability of each cultivar; three cultivars appeared to be more embryogenic, than others (BR-16, FT-Cometa and IAS-5). No significant differences in somatic embryo production were observed depending on the light intensity. The interactions light $\times$ $\mathrm{pH}$, auxin $\times \mathrm{pH}$, and cultivar $\times \mathrm{pH}$ were significant for ebryogenesis (Bonacin et al. 2000).

Investigation of soybean plantlet development from somatic embryos in vitro under mono- and polychromatic radiation using the LEDs was the aim of our research, in order to find the optimal spectrum for development of fullfledged plantlets.

\section{MATERIAL AND METHODS Plant material and culture conditions}

Soybean cultivar 'Primorskaya 28' was used for the experiments. Immature cotyledons were used to induce somatic embryogenesis. The immature beans were selected 7-14 days after flowering (Fig. 1). They were surface sterilized for 5 min in $70 \%$ ethyl alcohol and at $0.1 \%$ Diocide solution for $5 \mathrm{~min}$, followed by three washes in sterile distilled water after
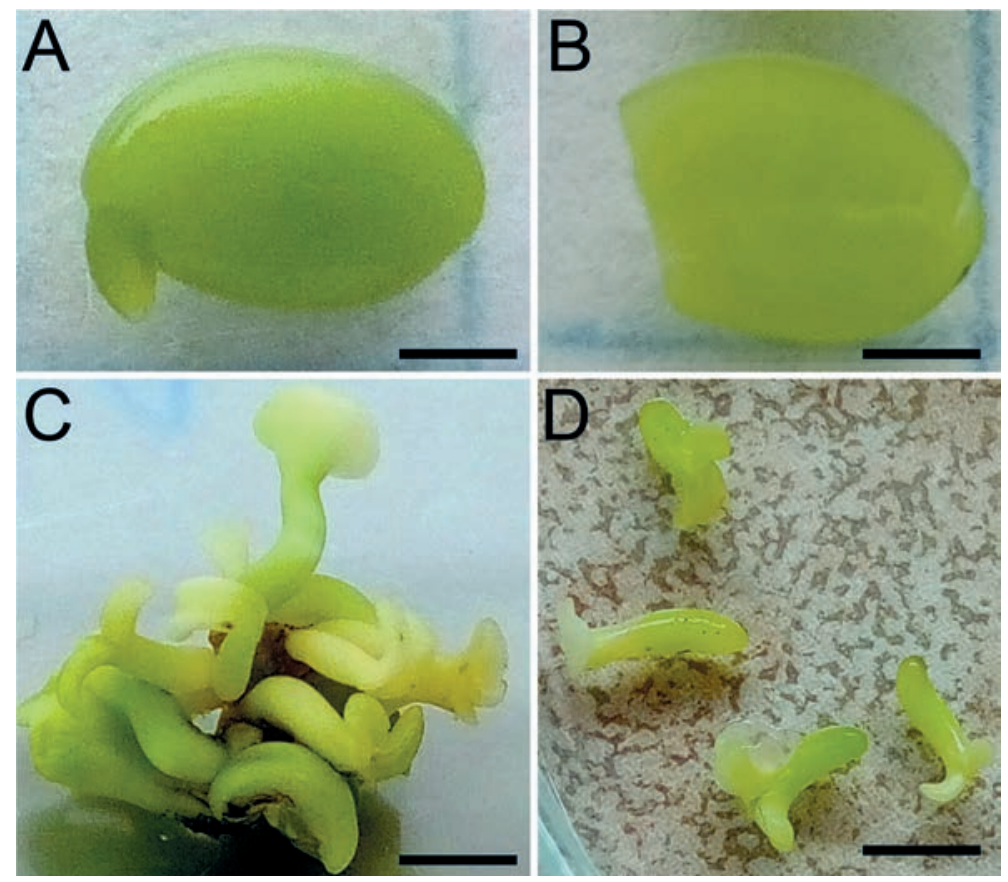

Figure 1 Immature seed from pod and somatic embryos of Glycine max (L.) Merr. A - immature seed from pod; B - truncated immature cotyledon (explant); C - somatic embryos (or embryoids) with normal and abnormal morphologies; D - somatic embryos selected for the experiment in the cotyledonary stage of development. Scale bar $=0.25 \mathrm{~cm}$ each treatment. Then, under aseptic conditions, the bean was cut and the seminal membrane of the seed was removed. At this stage of development, the cotyledons should be light green, not transparent and not dull. Immature cotyledons were isolated according to the Lazzeri technique (Lazzeri et al. 1985), cutting off the embryonic axis. Cotyledons (explants) up to $5 \mathrm{~mm}$ long were placed on nutrient medium containing vitamins, macro- and micro salts according to the MS prescription (Murashige \& Skoog 1962).

Embryogenesis was induced by phytohormone 2,4-dichlorophenoxyacetic acid (2,4-D) at concentration of $20 \mathrm{mg} / \mathrm{L}$. Test tubes with explants were placed in a culture room under controlled conditions $-25 \pm 1{ }^{\circ} \mathrm{C}$, relative humidity $50 \%, 16 / 8 \mathrm{~h}$ day/night photoperiod, illumination $48 \mu \mathrm{mol} /\left(\mathrm{m}^{2} \cdot \mathrm{s}\right)$ (2500 lux). After 30 days of cultivation, the explants with proembryonic cell complexes were transferred to a hormone-free growth medium (MS). Somatic embryos on cotyledonary stage of development were selected for the experiment and placed in boxes with different LEDs. Length of the plantlets was measured after one and two months of culturing. Growth index was calculated as 1-month-old embryoid height/initial embryoid height ratio for one-monthold embryos, and 2-month-old plantlet height/1-month-old embryoid height ratio for two-month-old plantlets.

\section{Light conditions}

Light irradiation with the intensity of $48 \mu \mathrm{mol} /\left(\mathrm{m}^{2} \cdot \mathrm{s}\right)$ was generated by LEDs with various spectra: cold white $(\mathrm{CW})$, white $(\mathrm{W})$, warm white (WW), full spectrum (FS, $450 \mathrm{~nm}$ and $660 \mathrm{~nm})$, red (R, $630 \mathrm{~nm})$, and blue (B, $440 \mathrm{~nm})$ (Fig. 2). Three variants of white light sources had the first emission maximum at approximately $440 \mathrm{~nm}$ corresponding to blue light, with different intensity for each type of white light. The second maximum corresponded to green-to-red spectrum within the wavelength range of $540-630 \mathrm{~nm}$. Fluorescent lamps OSRAM L 36W/765 were used as control illumination $(\mathrm{K})$ in the same climate conditions and photoperiod $(16 / 8 \mathrm{~h})$. An innovative LED light source sun box (SB) simulating the solar spectrum in the wavelength range of 440-660 $\mathrm{nm}$ was also used (detailed description in (Subbotin et al. 2018).

\section{Statistical analysis}

The data were processed using Statistica ver. 13.3. The results are represented as the means \pm standard errors of means and were tested by a paired Student's t-test and by analysis of variance (ANOVA), where statistical significance of differences between means was tested using Fisher's test. A difference of $\mathrm{p}<$ 0.05 was considered as statistically significant.

\section{RESULTS AND DISCUSSION}

The results showed that plantlets grown from embryoids differed in growth rates during two months of cultivation, depending on the light spectrum. The initial appearance of somatic embryos is shown in Fig. 3A. One- 
month-old somatic embryos and two-months-old soybean plantlets are shown in Fig. 3B, and Fig. 3C-3D, respectively.

During the first month of cultivation embryoids under FS spectrum were characterized with the highest growth rates, and were reliably higher than the embryoids exposed to K, CW, W, WW, and R spectra (Fig. 4). No difference was observed between these embryoid groups. Higher growth rate was also observed for embryoids exposed to SB spectrum with the growth increase coefficient of 1.8, against the data on the intact embryoid height, though it was not confirmed statistically.

Surprisingly, the lower growth rates were found for somatic embryos grown under R and B spectra - 1.62 and 1.59, respectively (Fig. 4). Formation of one, sometimes two and three roots and the first true leaves was found in plantlets grown under R and B spectra, as well as under FS, by the end of the first month of cultivation. Lower growth rate was observed in embryoids exposed to polychromatic spectra CW, W, WW, and K. The height increase coefficients were 1.49, 1.41, 1.19 , and 1.34 , respectively.

After two months of cultivation plantlets grown under FS were the highest among the experimental variants, and significantly differed in height from all plantlet groups except CW. No reliable difference was observed in growth indices between plantlets from other light groups. The growth rates for plantlets under CW and W spectra remained the same, while growth rates for plantlets under other light variants tended to slow down, comparing with the growth intensities during the first month of cultivation.

By the end of the experiment, the development of real leaves and roots was observed in plantlets of all experimental groups, but their sizes were larger for plantlets under R and FS lights (data not shown). Soybean plantlets that successfully developed from embryoids during the experiment, were adapted enough to be transferred into soil (Fig. 3C).

It is known that the spectral composition of light has a noticeable effect on organogenesis, with different wavelengths being more active at certain stages of organogenesis. For example, blue part of the spectrum contributed to shoot formation in callus of tobacco, while root initiation in Jerusalem artichoke callus occurred more intensively under red light (Timofeeva \& Rumyantseva 2012). Blue area of the spectrum is necessary to minimize the elongation of hypocotyls and petioles of lettuce seedlings, and is probably also necessary for any plants that grow due to the expansion of the hypocotyl and stem (Hoenecke et al. 1992). Liu et al. (2011) evaluated the response of Cherry tomato seedlings to various illumination spectra: red $(650 \mathrm{~nm})$, blue $(450 \mathrm{~nm})$, green $(520 \mathrm{~nm})$, yellow $(590 \mathrm{~nm})$, or combinations red:blue or red:blue:green. It was shown that combination of red:blue waves produced stronger, shorter tomato plants, while seedlings grown only under red LEDs had the longest hypocotyl.

In our experiment, the FS light, which can be considered as blue:red combination, also provided the best growth of soybean plantlets from somatic embryos, as compared to other light variants. Single red and blue lights did not provide any noticeable effect on plantlet development from embryoids and did not cause elongation or shortening of hypocotile, comparing with the control group. These data are in agreement with previously shown by Ushakova and colleagues for several soybean cultivars (Ushakova et al. 2016).

It is obvious that during the first month of cultivation spectral peculiarities of the white light sources (blue:greenred ratios) appeared to be insufficient for intensive soybean plantlet growth from embryoids. Monochromatic R and B light sources appeared to be also less effective in promoting

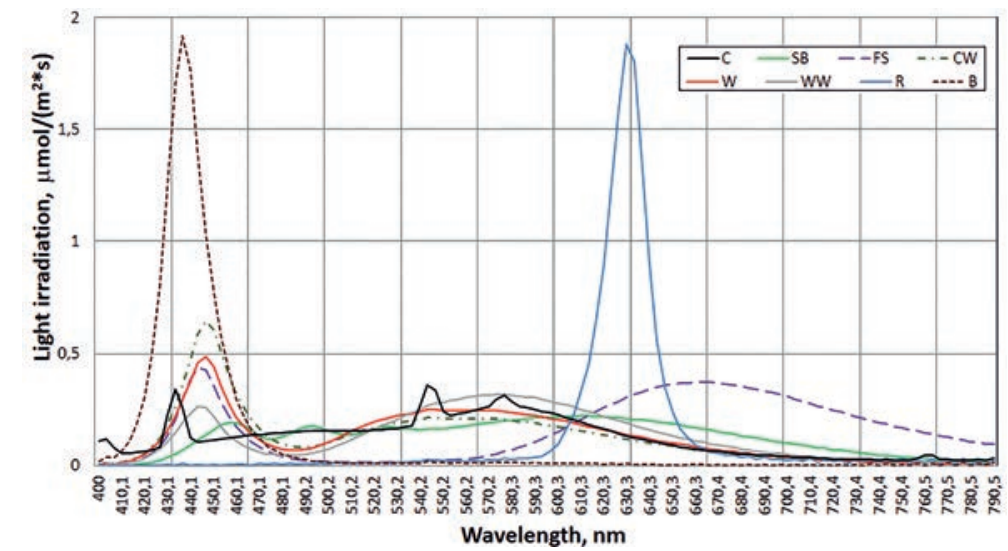

Figure 2 Spectra of LED light sources. $\mathrm{K}$ - white fluorescent, SB - sun box, CW - cold white, W - white, WW - warm white, FS - full spectrum $(450 \mathrm{~nm}$ and 660 $\mathrm{nm}), \mathrm{R}$ - red, B - blue light

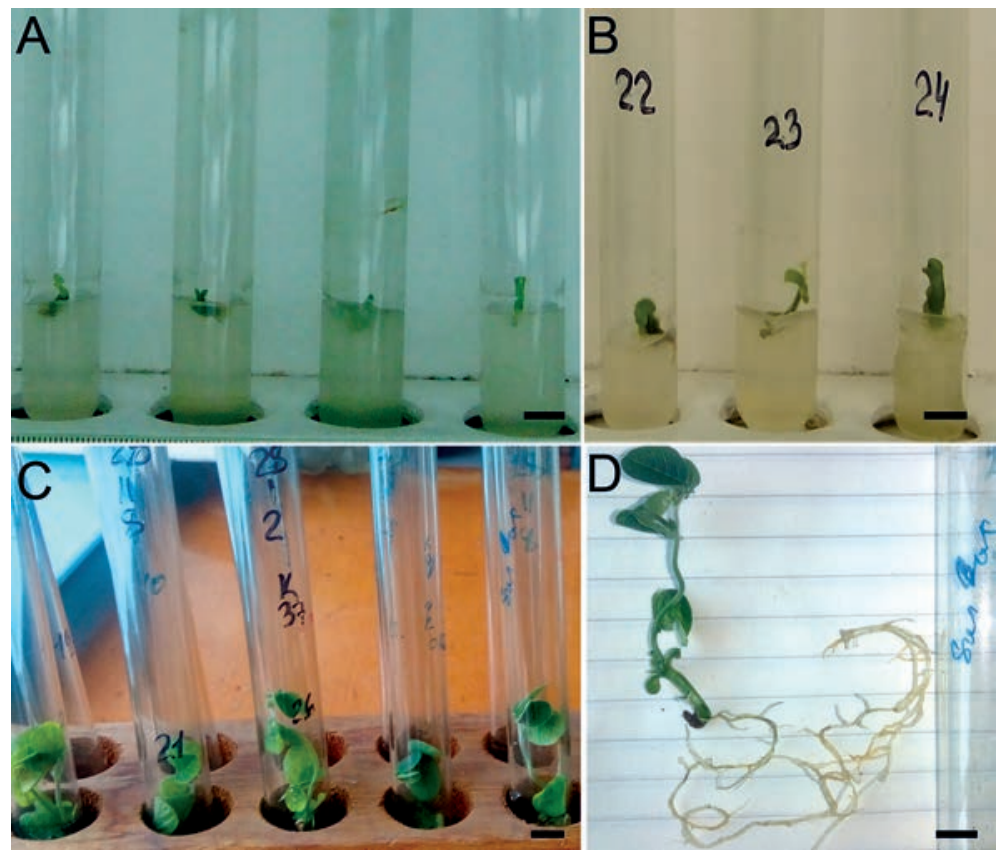

Figure 3 The somatic embryos of Glycine $\max (\mathrm{L}$.) Merr. growth under different light conditions: $\mathrm{A}-$ at the beginning of the experiment; $\mathrm{B}-$ one month later under the red spectrum as an example; $C, D$ - fully formed plantlets of soybean at the end of the experiment. Scale bar $=0.5 \mathrm{~cm}$ 


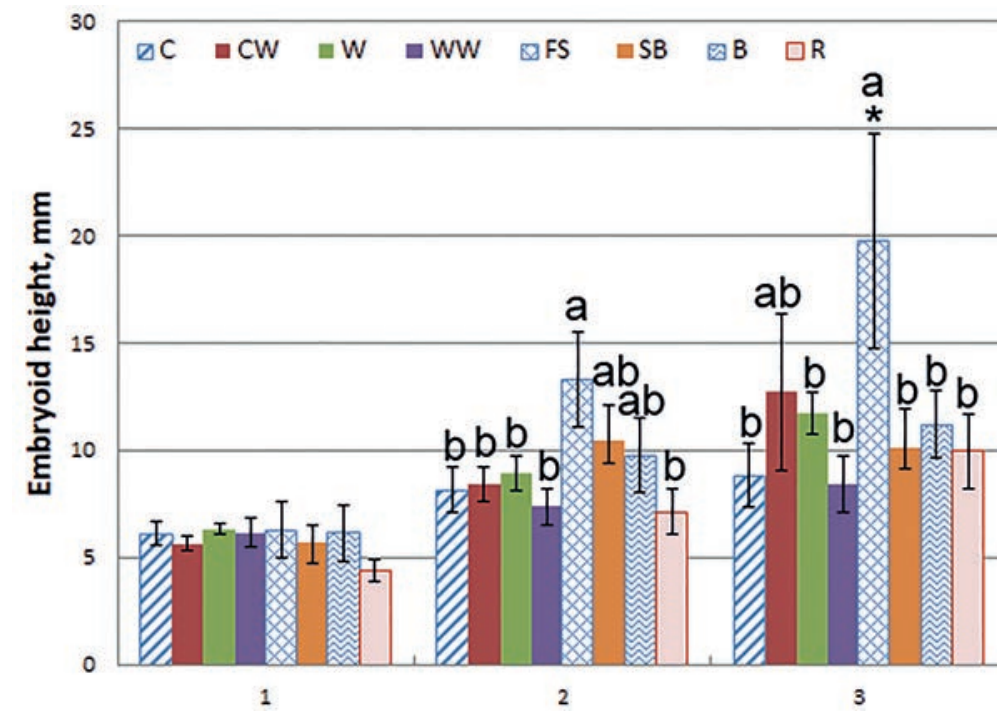

Figure 4 The diagram of Glycine max (L.) Merr. embryoids growth under different spectra at the beginning of the experiment (1), one (2) and two months (3) of culturing. Different letters above the columns indicate statistically significant differences of means $(p<0.05)$

plantlet development, than FS.

The difference of the FS light, in comparison with the white light varieties, is that the second emission peak is shifted to the red area, and includes wavelengths from 630 to $730 \mathrm{~nm}$, absent in the white lights spectra. As the CW, W, WW, and FS light variants have the first emission peak at the same wavelength, we can propose that the second red peak in the FS is responsible for the effect on soybean plantlet development.

Our experiments will be continued to find out more on the influence of the different spectra on soybean embryoid development, as the use of various lights instead of luminescent light seem to positively affect the plantlet transition from the embryoid phase to the phase of full-fledged plantlet ready to be transferred into soil.

\section{CONCLUSIONS}

The study of soybean (Glycine $\max (\mathrm{L}$.$) Merr. cv. 'Primor-$ skaya 28') somatic embryoids development under different spectra revealed that embryoids differ in growth rates during two months of cultivation, depending on the light spectrum. The plantlets under FS were characterized with the maximal height at the end of the experiment, showing that spectrum composition of the FS light source, with the presence of the red-far red wavelengths, in particular, was preferable for soybean plantlets growth among other light sources. Red LED showed no stimulating effect on plantlet growth. It seems that light with different spectra can be a potential non-chemical agent promoting the development of soybean somatic embryos into viable plants. Further studies will be conducted.

\section{ACKNOWLEDGEMENTS}

Financial support was provided by the Russian Science Foundation, Grant No. 20-1600016.

\section{LITERAT URE CITE D}

Bonacin, G.A., A.O. Mauro, R.C. Oliveira \& D. Perecin 2000. Induction of somatic embryogenesis in soybean: physicochemical factors influencing the development of somatic embryos. Genetics and Molecular Biology 23(4):865-868.

Hoenecke, M.E., R.J. Bula \& T.W. Tibbitts 1992. Importance of 'blue' photon levels for lettuce seedlings grown under red-lightemitting diodes. HortScience 27:427-430.

Larkin, P.J. \& W.R. Scowcroft 1981. Somaclonal variation - a novel source of variability from cell cultures for plant improvement. Theoretical and Applied Genetics 60:197-214.

Lazzeri, P.A., D.F. Hildebrand \& G.B. Collins 1985. A procedure for plant regeneration from immature cotyledon tissue of soybean. Plant Molecular Biology Reporter 3:160-167.

Liu, X.Y., S.R. Guo, Z.G. Xu \& X.L. Jiao 2011. Regulation of chloroplast ultrastructure, cross-section anatomy of leaves, and morphology of stomata of cherry tomato by different light irradiations of light emitting diodes. HortScience 46:217-221.

Murashige, T. \& F. Skoog 1962. A revised medium for rapid growth and bio-assays with tobacco tissue cultures. Physiologia Plantarum 15(3):473-497.

Timofeeva, O.A. \& N.I. Rumyantseva 2012. Cell culture and plant tissue. Izdatel'stvo Kazanskogo Federal'nogo Universiteta, Kazan, 91 рр. [Тимофеева О.А., Румянцева Н.И. 2012. Культура клеток и тканей растений. Казань: Изд-во Казанского федерального ун-та. 91 с.].

Subbotin, E.P., I.V. Gafitskaya, O.V. Nakonechnava, Y.N. Zhuravlev \& Y.N. Kulchin 2018. The influence of artificial sunlight and its intensity on the growth and development of Solanum tuberosum regenerants. Turczaninowia 21:32-39.

Ushakova, S.A., Ya.A. Grigoraschenko, V.N. Shikhov, V.E. Chernov \& A.A. Tikhomirov 2016. Light emission effect of LED irradiators on growth and development of soy of different varieties in the conditions of intensive light culture. Vestnic KrasGAU 7:28-35. [Ушакова С.А., Григоращенко Я.А., Шихов В.Н., Чернов В.Е., Тихомиров А.А. 2016. ВАияние спектра излучения светодиодных обмучателей на рост и развитие разАичных сортов растений сои в условиях интенсивной светокультуры // Вестник Красноярского государственного аграрного университета. Вып. 7. С. 28-35].

Williams, E.G. \& G. Maheswaran 1986. Somatic embryogenesis: factors influencing coordinated behaviour of cells as an embryogenic group. Annals of Botany 57:443-462. 